\title{
Effects of Different Pre-Germination Treatment Methods on the Germination and Seedling Growth of Yellow Passion Fruit (Passiflora edulis var. flavicarpa)
}

\author{
Arkendu Ghosh ${ }^{1}$, Koyel Dey ${ }^{1}$, Fatik Kumar Bauri ${ }^{1}$ and Amarendra Nath Dey ${ }^{2}$ \\ ${ }^{1}$ Department of Fruits and Orchard Management, Bidhan Chandra Krishi Viswavidyalaya, \\ Mohanpur, Nadia-741252, India \\ ${ }^{2}$ Department of Forestry, Uttar Banga Krishi Viswavidyalaya, Pundibari, \\ Cooch Behar-736165, India \\ *Corresponding author
}

\begin{tabular}{|c|c|}
\hline & A B S T R A C T \\
\hline & \\
\hline $\begin{array}{l}\text { Germination, } \\
\text { Passion fruit, } \\
\text { Seed dormancy, } \\
\text { Seedling growth, } \\
\text { Sulphuric acid. }\end{array}$ & \multirow{3}{*}{$\begin{array}{l}\text { Seeds from yellow passion fruit Passiflora edulis var. flavicarpa present dormancy } \\
\text { imposed by the seed coat. The present study aimed to evaluate some treatments to } \\
\text { overcome this dormancy for better germination. An experiment was conducted during } \\
2015 \text { to study the effect of different pre-sowing treatments on germination, vigour and } \\
\text { growth of passion fruit. The study showed significant differences among the treatments. } \\
\text { Maximum germination percentage }(89.51 \%) \text { and least mean germination time (11.67 days } \\
\text { after sowing) was observed in seeds treated with sulphuric acid for } 4 \text { minutes. Maximum } \\
\text { seedling height } 35.42 \mathrm{~cm} \text {, number of leaves } 11.20 \text { and vigour index ( } 3170.57) \text { were also } \\
\text { observed in seeds treated with sulphuric acid for } 4 \text { minutes and better result was also found } \\
\text { in } 10 \% \text { sucrose treatment. The use of pre-sowing treatment is therefore recommended as } \\
\text { an approach for propagation of passion fruits. }\end{array}$} \\
\hline Article Info & \\
\hline $\begin{array}{l}\text { Accepted: } \\
\text { 06 March } 2017 \\
\text { Available Online: } \\
10 \text { April } 2017\end{array}$ & \\
\hline
\end{tabular}

\section{Introduction}

Passion fruit (Passiflora edulis Sims.), a native of tropical America (Brazil), belongs to the family Passifloraceae is a high value and export oriented crop. Passion fruit stands out not only for its exotic and unique flavour and aroma but also for its amazing nutritional and medicinal properties. It is cultivated in countries like Kenya, Australia, New Zealand, Hawaii, South Africa and Srilanka. India, too, has its place in passion fruit history (Gurung et al., 2014). It has two cultivated edible types: the yellow passion fruit (Passiflora edulis var. flavicarpa) and the purple passion fruit (Passiflora edulis var. edulis). The former grows best under tropical conditions while the latter prefers subtropical climates. Besides showing higher fruit productivity and juice content, with higher acid content, the yellow passion fruit is tolerant to most of the soil borne pests and diseases that affect the purple type even though the latter has better flavor (Baiyeri et al., 2011). The 30-40\% juice content of passion fruit when extracted can be consumed fresh, used as concentrate or as flavours in certain foods (Alegbejo, 2004). The rind is used in cattle and pig feed, the glycoside passiflorine as a sedative and the fruit juice as a digestive stimulant and 
treatment for gastric ulcer. Besides, the oil, extracted from the seeds, with properties similar to sunflower and soybean oil, is edible and of industrial importance (Baiyeri et al., 2011). The fruit can be grown to eat or for its juice, which is often added to other fruit juices to enhance aroma. There is an increase in awareness of the crop and production areas under passion fruit. But limited information is available on propagation techniques. To increase the productivity, there should be availability of good planting material along with proper management practices. But seed dormancy has been reported for different Passiflora species, P. edulis (Hall et al., 2000), P. incarnate L. (Wehtje et al., 1985), P. mollissima (LaRosa, 1984) and P. nitida kunth (Passos et al., 2004). Most of the planting material is produced from seeds and there are reports that do not present satisfactory germination (Osipi, 2000). The germination of seeds of Passiflora is slow possibly due to the exogenous dormancy, which could be a combination of mechanical and chemical dormancy, the last one due to the presence of inhibitors in seeds (Delanoy et al., 2006). Since the seeds exhibit slow and less germination, pre-germination treatments may enhance the germination potential of passion fruit seeds. Hence the study was carried out to increase the germination potential of passion fruit seeds with various treatments.

\section{Materials and Methods}

\section{Seed collection}

Seeds were extracted from mature fruits and the aryl was removed from seeds by letting the seeds fermenting with the aryl for three days and removing it with a strainer. Seeds without aryl were allowed drying up for three days at room temperature $\left(20^{\circ} \mathrm{C}\right)$ in the darkness following the method of Cardenas et al., (2013).

\section{Seed pre treatments}

Seeds were pretreated as given below and then germination studies were carried out in 2015 in the Mondouri research farm, Bidhan Chandra Krishi Viswavidyalaya, Nadia, West Bengal, India. Germination pretreatments are: $T_{1}$ - Soaking of seeds in hot water for 1 minute, $\mathrm{T}_{2}$ - Soaking of seeds in hot water for 2 minutes, $\mathrm{T}_{3}$ - Soaking of seeds in hot water for 4 minutes, $\mathrm{T}_{4}$ - Soaking of seeds in sulphuric acid for 2 minutes, $\mathrm{T}_{5}$ - Soaking of seeds in sulphuric acid for 4 minutes, $\mathrm{T}_{6}-$ Soaking of seeds in sulphuric acid for 8 minutes, $\mathrm{T}_{7}-$ Soaking of seeds in sucrose at $5 \%, \mathrm{~T}_{8}-$ Soaking of seeds in sucrose at $10 \%$, $\mathrm{T}_{9}$ - Soaking of seeds in sucrose at $15 \%$ and $\mathrm{T}_{10^{-}}$Control (without pre treatment).

\section{Determination of germination percentage (G.P) and Mean germination time (MGT)}

Treated seeds were planted in black polythene bags with potting mixture. Emerging of radical and plumule were considered as indication of seed germination. Observations were recorded daily after the start of germination up to 45 days after sowing for each treatment and germination percentage was determined using the formula: G.P = (Total number of seed germinated/Total number of seeds sown in all replicates) x100. Mean germination time (MGT) was estimated by using the formula: MGT $=\sum(\mathrm{nt}) / \sum \mathrm{n}[\mathrm{n}=$ number of seeds newly germinating at time $t$, $\mathrm{t}=$ days from sowing] (Nichols and Heydecker, 1968).

\section{Post germination study}

After 90 days of seed sowing, five random seedlings from each replication were selected. Then the root portions were dipped in bucket of water to clean the adhered soil particles. Later, the seedlings were kept on blotting paper to soak extra water and their root and 
shoot lengths were measured with the help of digital slide caliper and expressed in centimeters $(\mathrm{cm})$. Seedling length was calculated by addition of shoot length and root length of respective seedling and expressed in centimeters $(\mathrm{cm})$.Seedling length $=$ Shoot length + Root length. Seedling Vigour Index reflects the health of the seedling produced and calculated on the basis of the following formula SVI= Germination percent $(\%)$ x Seedling length $(\mathrm{cm})$ (Abdualbaki and Anderson, 1973). After the separation of root, shoot and leaves, number of leaves and roots were counted and weight was taken separately with the help of electronic (digital) balance [Mettler Toledo PB 153-L] and expressed in gram (g). After taking fresh mass of root and shoot, they were kept in the oven at $80^{\circ} \mathrm{C}$ for 72 hours and reweighed until a constant weight had reached. Weight was taken with the help of electronic (digital) balance [Mettler Toledo PB 153-L] and expressed in gram (g).

\section{Experimental design and statistical analysis}

This experiment had a randomized block design with 10 treatments and 3 replications. Analysis of variance (one way classified data) for each parameter was performed using op stat software (online version). The statistical analysis was done by following randomized block design (RBD) as per Gomez and Gomez (1984). The significance of different sources of variation was tested by error mean square by Fischer-Snedecor's ' $F$ ' test at probability level of 0.05 percent.

\section{Results and Discussion}

\section{Germination percentage $(\%)$}

Pre-germination treatments of passion fruit seeds by acid scarification for 4 minutes gave the highest germination percentage of
$89.51 \%$, followed by acid scarification for 2 minutes with $80.15 \%$, while the minimum germination $(30.15 \%)$ observed from untreated seeds (Table I). Soaking passion fruit seeds in $10 \%$ sucrose solution had significantly $(\mathrm{P} \leq 0.05)$ higher germination percentage of $75.55 \%$ compared to soaking in hot water for 2 minutes and control, which gave germination percentage of $51.27 \%$ and $30.15 \%$, respectively (Table 1 ).

\section{Mean germination time (Days after sowing)}

From table 1 it was indicated that mean germination time of seeds ranged from 11.67days to 29.67 days. Lowest value of mean germination time (11.67days) was obtained in $\mathrm{T}_{5}$ followed by $\mathrm{T}_{4}$ (Soaking of seeds in sulphuric acid for 2 minutes) (13.33days) whereas highest value (29.67days) was obtained in $\mathrm{T}_{10}$. The data pertaining on mean germination time were statistically significant under all the treatments.

\section{Shoot, root and seedling length $(\mathrm{cm})$}

Sulfuric acid scarification for 4 minutes gave the highest shoot, root and seedling length $(22.54 \mathrm{~cm}, 12.88 \mathrm{~cm}, 35.42 \mathrm{~cm})$ of passion fruit seedlings three months after germination, followed by sulfuric acid pre-germination treatment for 2 minutes, which gave length of $20.87 \mathrm{~cm}, \quad 11.23 \mathrm{~cm}, 32.10 \mathrm{~cm}$; while the control gave the lowest length of $9.92 \mathrm{~cm}$, $5.88 \mathrm{~cm}$ and $15.88 \mathrm{~cm}$ (Table 1).

\section{Vigour index}

Seedling vigour index represents the determination of potential level of activity and performance of seed during germination and growth stage of the seedlings. Results (Table 1) showed that seedling vigour index of seedlings ranged from 476.41 to 3170.57 . Maximum seedling vigour index (3170.57) 
was obtained in $\mathrm{T}_{5}$ followed by $\mathrm{T}_{4}$ (2573.09) and lowest value (476.41) was obtained in $\mathrm{T}_{10}$ (Untreated seeds) and it was statistically significant under all the treatments.

\section{Number of leaves and roots per seedling}

The number of leaves and roots per seedling (Table-2) was maximum with Sulfuric acid scarification for 4 minutes after 90 days of sowing (11.20 and 11.27) followed by acid soaking for 2 minutes (10.20 and 10.47) whereas control recorded the minimum number of leaves and roots (3.53 and 4.40).

\section{Root fresh and dry mass (g)}

Sulfuric acid scarification for 4 minutes gave the highest fresh and dry mass of roots of
$2.53 \mathrm{~g}$ and $0.82 \mathrm{~g}$, measured 90 days after sowing, followed by sulfuric acid scarification for 2 minutes, which gave fresh and dry mass of $2.32 \mathrm{~g}$ and $0.68 \mathrm{~g}$, while the control gave the lowest value of $0.33 \mathrm{~g}$ and $0.19 \mathrm{~g}$ respectively (Table 2 ).

\section{Shoot fresh and dry mass (g)}

It is evident from the data presented in Table 2 that fresh and dry shoot mass of seedlings of yellow passion fruit ranged from $0.77 \mathrm{~g}$ to $3.18 \mathrm{~g}$ and $0.43 \mathrm{~g}$ to $1.38 \mathrm{~g}$ respectively. Maximum fresh and dry shoot mass $(3.18 \mathrm{~g}$ and $1.38 \mathrm{~g}$ ) was obtained in $\mathrm{T}_{5}$ followed by $\mathrm{T}_{4}$ $(2.81 \mathrm{~g}$ and $1.14 \mathrm{~g})$. Lowest mass $(0.77 \mathrm{~g}$ and $0.43 \mathrm{~g}$ ) was obtained in $\mathrm{T}_{10}$ (Untreated seeds). The data were statistically significant under all the treatments.

Table.1 Effects of pre-germination treatments of yellow passion fruit seeds three months (90 days) after sowing

\begin{tabular}{lcccccc}
\hline Treatments & $\begin{array}{c}\text { Germination } \\
(\%)\end{array}$ & $\begin{array}{c}\text { Mean } \\
\text { Germination } \\
\text { Time (Days } \\
\text { after sowing) }\end{array}$ & $\begin{array}{c}\text { Shoot } \\
\text { length } \\
(\mathrm{cm})\end{array}$ & $\begin{array}{c}\text { Root } \\
\text { length } \\
(\mathrm{cm})\end{array}$ & $\begin{array}{c}\text { Seedling } \\
\text { length }(\mathrm{cm})\end{array}$ & $\begin{array}{c}\text { Vigour } \\
\text { index }\end{array}$ \\
\hline $\mathrm{T}_{1}$ & $45.88(42.62)$ & 26.33 & 11.42 & 8.04 & 19.46 & 892.97 \\
$\mathrm{~T}_{2}$ & $51.27(45.71)$ & 23.67 & 12.25 & 8.76 & 21.01 & 1077.17 \\
$\mathrm{~T}_{3}$ & $40.20(39.34)$ & 26.33 & 10.11 & 7.26 & 17.37 & 698.34 \\
$\mathrm{~T}_{4}$ & $80.15(63.52)$ & 13.33 & 20.87 & 11.23 & 32.10 & 2573.09 \\
$\mathrm{~T}_{5}$ & $89.51(71.08)$ & 11.67 & 22.54 & 12.88 & 35.42 & 3170.57 \\
$\mathrm{~T}_{6}$ & $69.92(56.71)$ & 18.00 & 16.13 & 10.09 & 26.22 & 1833.22 \\
$\mathrm{~T}_{7}$ & $63.81(53.00)$ & 19.67 & 15.18 & 9.89 & 25.07 & 1599.81 \\
$\mathrm{~T}_{8}$ & $75.55(60.34)$ & 17.33 & 18.26 & 10.90 & 29.16 & 2203.19 \\
$\mathrm{~T}_{9}$ & $57.94(49.55)$ & 23.67 & 13.73 & 9.16 & 22.89 & 1326.16 \\
$\mathrm{~T}_{10}$ & $30.15(33.29)$ & 29.67 & 9.92 & 5.88 & 15.80 & 476.41 \\
$\mathrm{SEm}( \pm)$ & 0.05 & 1.53 & 0.06 & 0.05 & 0.07 & 4.27 \\
$\mathrm{LSD}$ & 0.08 & 2.16 & 0.08 & 0.07 & 0.10 & 6.04 \\
$(\mathrm{P} \leq 0.05)$ & & & & & & \\
\hline
\end{tabular}


Table.2 Effects of pre-germination treatments on seedling characteristics of yellow passion fruit seeds three months (90 days) after sowing

\begin{tabular}{lcccccc}
\hline Treatments & $\begin{array}{c}\text { No. of } \\
\text { leaves/seedling }\end{array}$ & $\begin{array}{c}\text { No. of } \\
\text { roots/seedling }\end{array}$ & $\begin{array}{c}\text { Root fresh } \\
\text { mass }(\mathrm{g})\end{array}$ & $\begin{array}{c}\text { Root dry } \\
\text { mass }(\mathrm{g})\end{array}$ & $\begin{array}{c}\text { Shoot fresh } \\
\text { mass }(\mathrm{g})\end{array}$ & $\begin{array}{c}\text { Shoot dry } \\
\text { mass }(\mathrm{g})\end{array}$ \\
\hline $\mathrm{T}_{1}$ & 5.33 & 5.47 & 1.04 & 0.27 & 1.18 & 0.54 \\
$\mathrm{~T}_{2}$ & 6.07 & 5.67 & 1.15 & 0.26 & 1.38 & 0.56 \\
$\mathrm{~T}_{3}$ & 4.47 & 5.13 & 0.84 & 0.20 & 1.07 & 0.45 \\
$\mathrm{~T}_{4}$ & 10.20 & 10.47 & 2.32 & 0.68 & 2.81 & 1.14 \\
$\mathrm{~T}_{5}$ & 11.20 & 11.27 & 2.53 & 0.82 & 3.18 & 1.38 \\
$\mathrm{~T}_{6}$ & 8.80 & 8.40 & 1.88 & 0.45 & 2.25 & 0.99 \\
$\mathrm{~T}_{7}$ & 7.40 & 7.47 & 1.44 & 0.37 & 2.05 & 0.79 \\
$\mathrm{~T}_{8}$ & 9.40 & 9.20 & 2.12 & 0.51 & 2.49 & 1.04 \\
$\mathrm{~T}_{9}$ & 6.87 & 6.67 & 1.29 & 0.30 & 1.78 & 0.65 \\
$\mathrm{~T}_{10}$ & 3.53 & 4.40 & 0.33 & 0.19 & 0.77 & 0.43 \\
$\mathrm{SEm}( \pm)$ & 0.13 & 0.17 & 0.02 & 0.02 & 0.02 & 0.02 \\
$\mathrm{LSD}$ & 0.18 & 0.24 & 0.03 & 0.03 & 0.02 & 0.03 \\
$(\mathrm{P} \leq 0.05)$ & & & & & & \\
\hline
\end{tabular}

This study has shown that chemical scarification of passion fruit seeds increased germination percentage. Previous studies have shown that chemical seed treatment improved seed germination and growth under various conditions (Kozlowski, 1972; Ehiagbanare and Onyibe, 2007; Mabundza et al., 2010). According to Ehiagbanare and Onyibe (2007) seed pre-treatments and pre-treatment duration affected commencement of germination in Tetracarpidium conophorun. Seeds treated for 5 min with concentrated sulfuric acid had the highest percentage germination of $66 \%$ followed by de-pulped, but un-treated seeds, which had $57 \%$. Kozlowski (1972) attributed early germination of seeds after scarification to cracks, which permit water and gases into the seed resulting in enzymatic hydrolysis and thus transforming the embryo into a seedling. In this study the use of sucrose solution as a priming agent provided better result in yellow passion fruit. According to Mabundza et al., (2010), germination and early growth requires a supply of readily available substrate (e.g. sucrose) other than that derived from hydrolysis of major stored reserves. Sucrose is utilised before radicle emergence prior to mobilization of the major carbohydrates stored reserves. Therefore, treating passion fruit seeds with sucrose probably provided a supply of readily available carbohydrates for respiration during germination and development of seedling's roots. Sucrose is a major form in which the products of carbohydrates catabolism are translocated into developing seedlings (Esau, 1977). Seed priming increases crop yield possibly by modulating enzymes of sucrose metabolism in chickpea (Anonymous, 2007). Results obtained in an experiment indicated that the pre-germination treatment of passion fruit seeds by using $\left(\mathrm{H}_{2} \mathrm{SO}_{4}\right)$ enhanced germination of the seeds by breaking dormancy (Mabundza et al., 2010). The best result to overcome dormancy in Passiflora cincinnata Mast were achieved by seeds under shade conditions, followed by treatment with hot water at $50^{\circ} \mathrm{C}$, or alternatively seeds should be dried under shade followed by scarification. Hot water soaking might lead to the loosening of the seed coat wall, allowing water to permeate into the tissues, leading to physiological changes promoting embryo growth (Oliveira et al., 2010). 
In conclusion yellow passion fruit seeds exhibit physical dormancy due to the hard seed coat, which affects the seed germination. Results obtained in this experiment indicated that the pre-germination treatment by using $\mathrm{H}_{2} \mathrm{SO}_{4}$ for 4 minutes enhanced germination and seedling growth most effectively and $10 \%$ sucrose solution also gave the next best results in breaking seed dormancy, promotion of growth and development of seedlings. It is recommended for farmers that sulfuric acid was the most effective in breaking dormancy in passion fruit seeds in this investigation. However, in cases whereby farmers have got limited resources (e.g., capital), they can ferment the passion fruit seeds in $10 \%$ sucrose solution, which gave the next best results.

\section{Acknowledgement}

The authors gratefully acknowledge Department of Fruits and Orchard Management, Faculty of Horticulture, Bidhan Chandra Krishi Viswavidyalaya for the valuable technical, laboratorial and financial support during the experiment.

\section{Conflict of interests}

There is no conflict of interests regarding this research paper.

\section{References}

Abdul-baki, A. and Anderson, J.D. 1973. Vigor determination in soybean seed by multiple criteria. Crop Sci., 13: 630633.

Alegbejo, M.D. 2004. Growing passion fruit in Northern Nigeria. Horticulture Magazine, 2: 9.

Anonymous. 2007. The Role of Sucrose Transporter in Germination. http://www.jxb.oxford jornals.org/cgi/ content/abstract. 10/04/07.

Baiyeri, K.P., Ugese, F.D. and Uchendu, T.O. 2011. The effects of previous fertilizer treatments on passion fruit seed quality, and seedling emergence and growth qualities in soilless media. J. Agri. Technol., 7(5): 1397-1407.

Cárdenas, J., Carranza, C., Miranda, D. and Magnitskiy, S. 2013. Effect of $\mathrm{GA}_{3}$, $\mathrm{KNO}_{3}$, and removing of basal Point of seeds on germination of sweet granadilla (Passiflora ligularis Juss) and yellow Passion fruit (Passiflora edulis f. Flavicarpa). Revista Brasileira de Fruiticultura, 35(3): 853-859.

Delanoy, M., Van Damme, P., Scheldeman, X. and Beltran, J. 2006. Germination of Passiflora mollissima (Kunth) L.H.Bailey, Passiflora tricuspis Mast. and Passiflora nov sp. Seeds. Scientia Horticulturae, 110: 198-203.

Ehiagbanare, J.E. and Onyibe, H.I. 2007. Effect of Pre-sowing Treatments on Seed Germination and Seedling Growth of Tetracarpidium conophorun Mull. http://www. academic journals.org/AJB. 20/03/07.

Esau, K. 1977. Anatomy of Seed Plants. John Wiley and Sons, New York.

Gomez, K.A. and Gomez, A.A. 1983. Problem data, pp. 275-315 in WileyInter science Publication (eds. John Wiley and Sons) Statistical procedures for Agri. Res., ( $2^{\text {nd }}$ audition). New York, USA.

Gurung, N., Swamy, G.S.K., Sarkar, S.K. and Ubale, N.B. 2014. Effect of chemicals and growth regulators on germination, vigour and growth of passion fruit (Passiflora edulis Sims.). The Bioscan, 9(1): 155-157.

Hall, R.M., Drew, R.A., Higgins, C.M. and Dietzgen, R.G. 2000. Efficient organogenesis of an Australian passion fruit hybrid (Passiflora edulis $\mathrm{x}$ Passiflora edulis var. flavicarpa) suitable for gene delivery. Australian J. Bot., 48: 673-680.

Kozlowski, T.T. 1972. Seed Biology. 
Academic Press, New York, USA.

La Rosa, A.M. 1984. The biology and ecology of Passiflora mollissima in Hawaii. In Technical Report. Cooperative National Park Resources Studies Unit. p. 50

Mabundza, R.M., P.K. Wahome and Masarirambi, M.T. 2010. Effects of different pre-germination treatment methods on the germination of passion (Passiflora edulis) seeds. J. Agri. Society of Sci., 6: 57-60.

Nichols, M.A. and Heydecker, W. 1968. Two approaches to the study of germination data. Proceedings of International Seed Testing Association, 33: 531-540.

Oliveiria, Jr M.X., Sao Jose A.R., Reboucas, T.N.H., Morais, O.M. and Dourado, F.W.N. 2010. Overcoming seed dormancy of passion fruit (Passiflora cincinnata Mast.). Revista Brasileira de
Fruiticultura, 32: 584-590.

Osipi, E.A.F. 2000. Effect of temperature, fruit ripening and storage on physiological quality of seeds of passion fruit sweet (Passiflora alata Dryander). Thesis (Ph.D. Horticulture) Faculty of Agricultural Sciences, University Estadual Paulista, Botucatu.

Passos, I.R.S., Matos, G.V.C., Meletii, L.M.M., Scott, M.D.S., Bemacci, L.C. and Vieira, M.A.R. 2004. Gibberellic acid utilization for dormancy break in Passiflora nitida Kunth seeds in vitro germinated. Revista Brasileira de Fruiticultura, 26: 380-381.

Wehtje, G., Reed, R.B. and Dute, R.R. 1985. Reproductive biology and herbicidal sensitivity of maypop passion flower (Passiflora incarnata). Weed Sci., 33: 484-490.

\section{How to cite this article:}

Arkendu Ghosh, Koyel Dey, Fatik Kumar Bauri and Amarendra Nath Dey. 2017. Effects of Different Pre-Germination Treatment Methods on the Germination and Seedling Growth of Yellow Passion Fruit (Passiflora edulis var. flavicarpa). Int.J.Curr.Microbiol.App.Sci. 6(4): 630-636. doi: https://doi.org/10.20546/ijcmas.2017.604.077 